\title{
Wood Quality Characterization of Sycamore Maple (Acer pseudoplatanus L.) and its Utilization in Wood Products Industries
}

\author{
Tomislav Sedlar, Bogoslav Šefc, Srđan Stojnić, Tomislav Sinković
}

\begin{abstract}
This study quantified the physical and mechanical properties of sycamore maple (Acer pseudoplatanus L.) as a basis for assessing wood quality. The physical properties of oven-dry density, density at $12 \%$ MC, green density, basic density, longitudinal, radial, tangential and volumetric shrinkages were tested and the mechanical properties of bending strength, modulus of elasticity at bending, compression strength parallel to grain and compression strength in radial and tangential direction as well as of Brinell hardness on the cross, radial, and tangential section were determined. Five sycamore maple trees from Medvednica region were selected for the purposes of this research. The results were compared with known literature data on sycamore maple wood, beech wood from the same sight, and beech wood from Gorski Kotar region. For a better understanding of sycamore maple physiology, as well as for assessing the quality of wood products, the distribution of wood properties within the tree radius, from pith to bark, was investigated. There was a general bell shaped distribution, in the radial direction, in wood density, and mechanical properties of sycamore maple wood. Shrinkages decreased from pith to bark, except for tangential shrinkage with bell shaped pattern. All investigated wood densities of sycamore maple from Medvednica were similar to the findings of studies known in literature, as well as shrinkages, except for the lower longitudinal shrinkage. Investigated mechanical properties of sycamore maple wood were similar to the findings of studies known in literature, except for the lower bending strength and modulus of elasticity (MOE). Investigated sycamore maple indicated better dimensional stability than beech wood from two locations in the region, although it did not match the beech wood regarding mechanical properties, especially wood hardness.
\end{abstract}

Keywords: sycamore maple (Acer pseudoplatanus L.), physical properties, mechanical properties, radial variations, wood quality

\section{Introduction}

Sycamore maple (Acer pseudoplatanus L.) is a fastgrowing noble broadleaved tree species that commonly grows in the mixed forests of Central Europe (Vacek et al. 2018). The natural distribution range of sycamore maple includes the mountainous regions of Southern, South-western, Western, Central, and Eastern Europe with the extreme easterly limit at the Caspian Sea (Fig. 1). Although the share of this species in the total forest area of Europe is quite low (e.g. around 3\%) (Spiecker et al. 2009), several studies have highlighted its great ecological and economic importance (Florineth et al. 2002, Leslie 2005, Bell 2009). Indeed, sycamore maple is recorded to promote biodiversity (Binggeli 1993), as well as positively affect the ecological stability of the forest by improving humus formation and cycling processes of elements and organic matter (Heitz and Rehfuess 1999). Likewise, rapid growth, valuable timber with multiple uses, and high market prices make sycamore maple economically attractive (Hein et al. 2009). For these reasons, certain authors believe that the area proportion of maple is going to be doubled in the long term (Thies et al. 2009).

Despite its valuable timber and moderate site requirements, this species is treated as a poor relation by breeders in most European countries. One reason for this might be the lack of acceptance of the species as a 
traditional forest tree (Krabel and Wolf 2013). The lack of relevant research on technical properties has also contributed to the underestimation of this wood species. In the past decades, the use of sycamore maple in the wood-processing industry was largely limited primarily as the consequence of intensive utilization of European beech, whose physical and mechanical wood properties are similar to those of maple. However, having in mind the negative influence of changing climate on beech populations in Central Europe (Gessler et al. 2007), the growing interest in the use of sycamore maple in forestry and timber industry might be expected. Indeed, besides the valuable timber, sycamore maple is known as a tree species with high adaptability to a broad range of site conditions, as well as highly competitive ability reflected through short generation turnover, good natural regeneration and regular seed set (Rusanen and Myking 2003, Simon et al. 2010, Vacek et al. 2018). According to Aitken et al. (2008) species are likely to adapt more quickly to altered environmental conditions if characterized by high fecundity, short generation lengths, and small seeds capable to disperse over a long distance. Vacek et al. (2018) reported that sycamore maple produces seeds every year starting around the age of 25 to 30 years. The seed is wind-dispersed usually within $200 \mathrm{~m}$ from the mother tree, although some records evidenced long-distance dispersal, up to $4 \mathrm{~km}$ (Pasta et al. 2016). On the other hand, mast years in beech occur at intervals of 2-20 years in the regions of Central and Northern Europe (Müller-Haubold et al. 2015), while seed dispersal was reported to be locally restricted (Sagnard et al. 2007).

Maple is characterized by good natural regeneration and fast growth in the juvenile development stage, having, therefore, a competitive advantage over co-occurring tree species (Vacek et al. 2018). According to Rusanen and Myking (2003), the annual growth of maple in the first years might be more than 1 meter, on the rich soils. In contrast, several authors demonstrated that beech trees need approximately 10 years to grow to breast height $(1.3 \mathrm{~m})$ (Samonil et al. 2009, Trotsiuk et al. 2012, Matović 2019). Another advantage of sycamore maple might also be shorter rotation (70-75 years) in comparison to European beech (app. 140 years), and therefore the production of high-quality timber within a shorter period (Hein et al. 2009, Mariotti et al. 2017). Finally, sycamore maple is considered as a species well adapted to projected climate changes in the region of Central Europe (Kölling and Zimmermann 2007, Kölling 2007). For example, while it is expected that sycamore maple grown in Germany adapt to elevated air temperatures and reduced precipitations
(Kölling and Zimmermann 2007), certain studies involving German populations of European beech documented their sensitivity to drought induced stress (Aranda et al. 2014, Stojnić et al. 2018).

In Europe, $1.7 \%$ of total annual cuttings consist of sycamore maple. Research claim that the future area proportion of ash, sycamore maple, and wild cherry in Europe will double; the future proportion of sycamore maple harvest could, therefore, increase remarkably (Thies et al. 2009). These three species currently cover $4.1 \%$ of the European forests and they are expected to reach up to $8.9 \%$ and $12.1 \%$ in German speaking countries alone (Thies et al. 2009). According to the Swiss National Forest Inventory, the sycamore maple population in Switzerland adds up to 11.8 Mio $\mathrm{m}^{3}$ and appears on the third position after beech $\left(73.3 \mathrm{Mio} \mathrm{m}^{3}\right)$ and ash $\left(14.8 \mathrm{Mio} \mathrm{m}^{3}\right)$ (Brändli 2010). Sycamore maple covers approximately $0.8 \%$ of forests in Croatia, while 36\% of forests are covered with beech wood (Sedlar et al. 2019).

Sycamore maple wood is hard and solid and is relatively easy to process. It is used for various purposes, from furniture making, carpentry, floor coverings to parts of ships and aircraft, and some special products of wood such as shoe moulds or pulleys. However, the most valuable wood consists of resonant maples of irregular structure used in the production of expensive and highly valued musical instruments and veneers. Such wood reaches a very high price on the market. High quality sycamore maple wood logs achieve a price between 140 to $320 € / \mathrm{m}^{3}$ in the Croatian market (Hrvatske šume 2019). Comparatively, the price of the same quality beech wood logs varies between 95 to $125 € / \mathrm{m}^{3}$. Concurrently, sycamore maple wood with irregular birds eye figure structure reaches a price of up to $550 € / \mathrm{m}^{3}$.

Physical and mechanical properties of wood are important indicators for wood quality prediction (Stamm and Sanders 1966, Zobel 1984, Savidge 2003, Saranpää 2003, Zhang 2003, Zink-Sharp 2003). Beech is the most common, most commercial and most explored domestic wood species. Technical properties of beech wood were the subject of much research in Europe (Gustafsson 2010, Skarvelis and Mantanis 2013, Lo Monaco 2014, etc.) as well as in Croatia (Štajduhar 1973, Petrić and Šćukanec 1980, Govorčin 1996, Govorčin et al. 2003, Sinković et al. 2011, Sedlar et al. 2019). Although sycamore maple is an attractive species in forestry, there is a lack of peer reviewed, scientifically based investigations into its silviculture (Hein et al. 2008) and its technical properties. Available information on technical properties of sycamore maple wood are modest, and science-based information on 


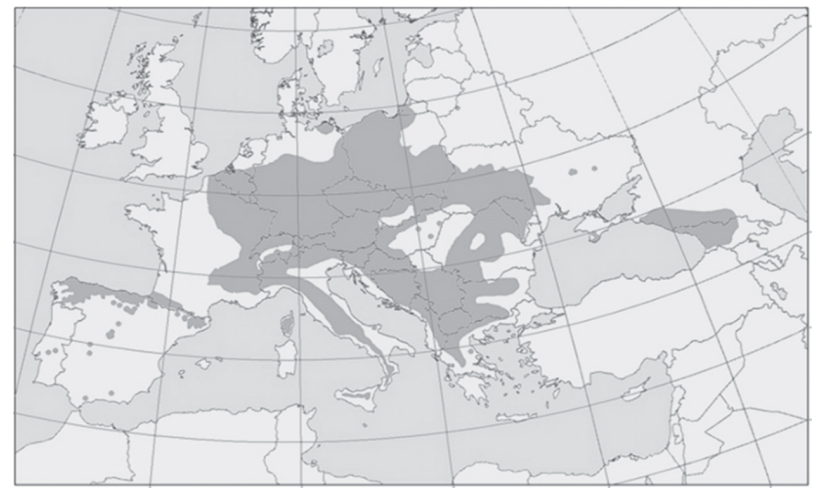

Fig. 1 Natural distribution area of sycamore maple (Acer pseudoplatanus L.) in Europe (Source: EUFORGEN, 2009., www.eufrogen. org)

many important technical properties are missing. A review of the literature reveals that sycamore maple wood has a slightly lower density and strength compared to beech wood (Wagenführ 2007). At the same time, sycamore maple wood is more dimensionally stable (Ehmcke and Grosser 2014). Because of all the above, the physical and mechanical properties of sycamore maple wood were investigated.

The main objectives of this study were to: 1 . Investigate and analyze physical and mechanical properties of sycamore maple (Acer pseudoplatanus L.) wood from the area of the Medvednica mountain, and to determin their radial distribution, from pith to bark; 2 . Compare physical and mechanical properties of sycamore maple wood from Medvednica with the properties of sycamore maple wood from available literature; 3. Compare the physical and mechanical properties of sycamore maple wood from Medvednica with investigated properties of beech (Fagus sylvatica L.) wood from the same location and beech wood from Gorski Kotar.

\section{Materials and Methods}

For the purpose of investigating the physical and mechanical properties, trees were selected from the forest on the northern slope of the Medvednica mountain in Croatia, which is a part of the »Training and Forest Research Centre Zagreb «.

According to Vukelić (1998), the dominant forest community of Medvednica is the beech-fir forest of the Pannonian part of Croatia (Abieti-Fagetum "pannonicum «). These forests continue to the strongly expressed vegetation belt of mountain beech forests. In the layer of trees, beech and fir predominate, followed by large-leaved linden and sycamore maple, while common hornbeam appears at the lower altitudes. A

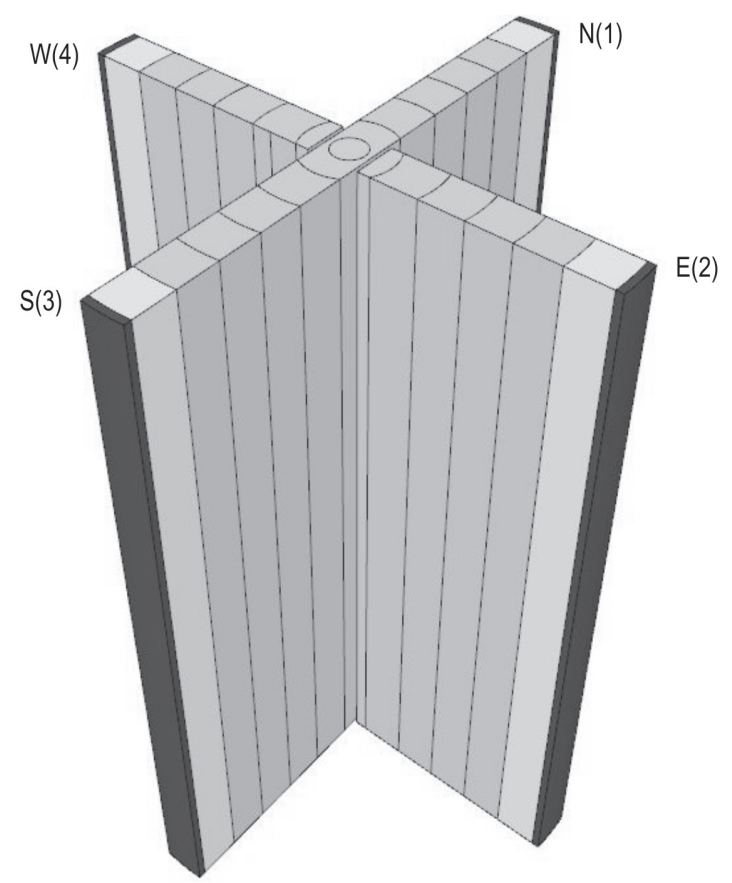

Fig. 2 Bark to pith cores (north-south, east and west)

mixed community of sycamore maple and common ash (Chrysanthemo macrophylli-Aceretum pseudoplatani, Horvat 1938) occur between 800 and 1000 meters in elevation.

Five dominant trees were felled for the analysis according to ISO 3129:2012. The mean diameter at $1.3 \mathrm{~m}$ (DBH) for all trees was $0.49 \mathrm{~m}$. Trees were healthy and the first branches noted along the trunk were at a height of approximately $10 \mathrm{~m}$ upwards. If these trees were exploited, the basal log length would be at least $14 \mathrm{~m}$ long. Once felled, a $1.0 \mathrm{~m}$ long log was sawn at a height of $1.3 \mathrm{~m}$ from all trees. Below this height, buttressing can occur along the length of the stem bole, which may influence the results. Boards were then cut through the center of the log, so that the whole crosssection, from bark to pith, could be used for further sampling. One whole core was oriented north-south $(\mathrm{N}-\mathrm{S})$, and the others were partial from the core to the east (E) and from the core to the west side (W) (Fig. 2).

All boards were then stored and submitted to natural drying until equilibrium moisture content reached $12 \%$ with a constant mass. The boards were then cut into smaller samples in the radial direction from pith to bark (Fig. 3). Each sample was labelled with an indication of tree number, geographical orientation, and the position regarding cambial age. The growth ring closest to the centre of the sample was used as the indicator of cambial age for that sample. 

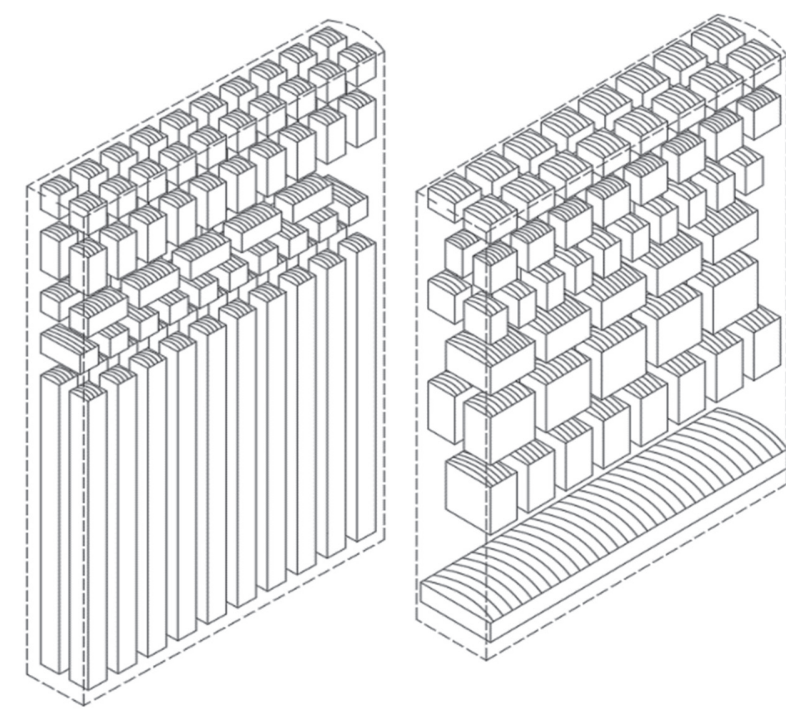

Fig. 3 Small clear wood samples for testing physical and mechanical properties of wood

The physical properties investigated in this study were oven-dry density, basic density, and density at 12\% MC according to ISO 13061-2:2014, longitudinal, radial and tangential shrinkage according to ISO 13061-13:2016, volumetric shrinkage according to ISO 13061-14:2016, moisture content according to ISO 13061-1:2014 and annual ring width according to EN 1309-3:2018.

The mechanical properties investigated in this study were compression strength in the longitudinal, radial and tangential direction according to ISO 1306117:2017 and ISO 13061-5:2020, bending strength according to ISO 13061-3:2014, modulus of elasticity according to ISO 13061-4:2014, Brinell hardness on the cross, radial and tangential section according to ISO 13061-12:2017.

Statistical analysis of data and their comparison were carried out in Statistica 8. Data were analyzed and presented as the minimum, mean and maximum values. The simple linear regression model was used to analyze the relationship between oven dry density and shrinkages (Table 2), annual ring width and densities (Table 3), density at 12\% MC, and mechanical properties (Table 4).

To facilitate the comparison of results with the literature, the average values of three radial areas (inner, middle and outer) were computed for all cores: the inside area value was obtained by averaging the first sample from the pith, the outside area value by averaging the last sample, closest to the bark and the middle area value by averaging the remaining samples (Fig. 4).

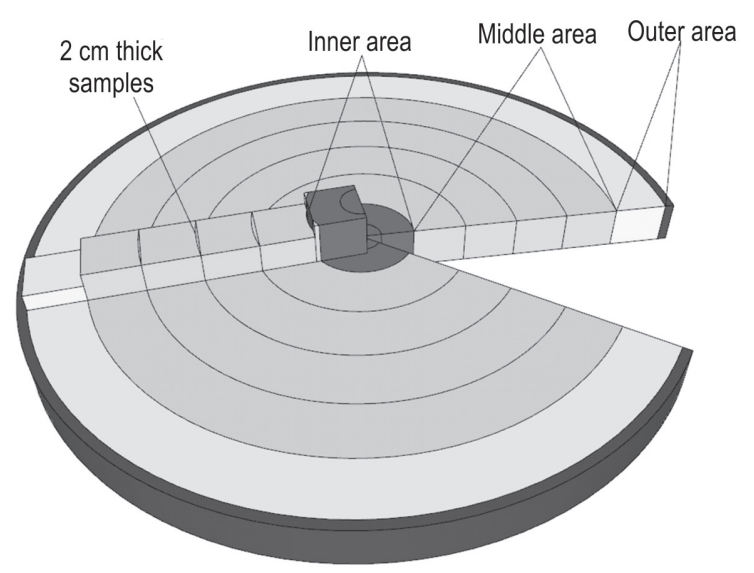

Fig. 4 Division of the core into 2-cm-thick samples and into inner, middle and outer areas

The resulting data should be comparable to those of Woodcock and Shier (2002), Plourde et al. (2015) and Longuetaud et al. (2017), who measured specific gravity on $2 \mathrm{~cm}$ core segments and evaluated radial variations using the inside segment, outside segment, and the average of all other segments. Pairwise, comparisons between groups were done with the analysis of variance (One-way ANOVA) adjusted using Tukey HSD correction for multiple comparisons.

To complete the information given by the above analyses, radial curves of variations and the corresponding trends are given in Appendices A.

\section{Results and Discussion}

\subsection{Physical and Mechanical Properties}

Statistical values of physical and mechanical properties of sycamore maple wood from Medvednica, as well as, physical and mechanical properties of sycamore maple (Wagenführ 2007, Ehmcke and Grosser, 2014) and beech wood from the same region (Štajduhar 1973) and beech wood from Gorski Kotar (Govorčin 1996) are shown in Table 1.

Oven-dry wood density, density at $12 \% \mathrm{MC}$, green wood density, and basic density of investigated sycamore maple were $0.59,0.63,1.08$, and $0.51 \mathrm{~g} / \mathrm{cm}^{3}$, respectively, and were similar to the findings of Wagenführ (2007) and Ehmcke and Grosser (2014).

Differential shrinkage was determined for the longitudinal, radial, and tangential directions at a ratio of 1:33:72. Measured longitudinal shrinkage of $0.13 \%$ was unusually low for sycamore maple wood. According to Ehmcke and Grosser (2014), for example, it was 
$0.45 \%$, which is similar to the value of $0.5 \%$ stated by Wagenführ (2007).

Radial, tangential and volumetric shrinkages of 4.3 , 9.3 and $14.0 \%$, respectively, were similar to the findings of Wagenführ (2007) and Ehmcke and Grosser (2014) although slightly greater.

Compression strength in longitudinal, radial and tangential (L:R:T) direction was 45.5, 16.0, 10.7\%, respectively. The results are similar to the findings of Wagenführ (2007), Sonderegger et al. (2013), and Ehmcke and Grosser (2014).

Bending strength and MOE were 88.5 MPa and 8.6 GPa, respectively, and were lower than the same findings of Wagenführ (2007) and Ehmcke and Grosser (2014).

Brinell hardness was measured on three different wood sections, cross, radial and tangential, and was $51.4,24.9$, and $31.5 \mathrm{~N} / \mathrm{mm}^{2}$, respectively. These find- ings were similar to Wagenführ (2007) and Ehmcke and Grosser (2014).

Mean values of investigated sycamore maple from Medvednica were compared with summed average values of beech wood from investigations of Štajduhar (1973) and Govorčin (1996). Densities of beech wood were approximately $10 \%$ greater than those of sycamore maple wood. Greater density was the main reason why mechanical properties were also greater in beech wood $(18,20,27$ and 52\% for compression strength parallel to the grain, bending strength, MOE, and Brinell hardness, respectively). Although average annual ring width of sycamore maple was $20 \%$ greater than that of beech wood from the same location and even $220 \%$ greater than that of beech wood from Gorski Kotar, shrinkages were lower than in beech wood $(100,30,25,20 \%$ for longitudinal, radial, tangential and volumetric shrinkage, respectively).

Table 1 Comparison of physical and mechanical properties of sycamore maple wood with reference to sycamore maple (Wagenführ 2007, Ehmcke and Grosser 2014) and beech wood from the same region (Štajduhar 1973) and beech wood from Gorski Kotar (Govorčin 1996)

\begin{tabular}{|c|c|c|c|c|c|}
\hline & Wagenführ 2007 & $\begin{array}{l}\text { Ehmcke and } \\
\text { Grosser } 2014\end{array}$ & Present research & Štajduhar 1973 & Govorčin 1996 \\
\hline Annual ring width (ARW), mm & - & - & $0.15 \ldots 3.18 \ldots 10.3$ & $0.7 \ldots 2.7 \ldots 11.8$ & $0.05 \ldots 0.99 \ldots 6.06$ \\
\hline Oven-dry wood density $\left(\rho_{0}\right), \mathrm{g} / \mathrm{cm}^{3}$ & $0.48 \ldots 0.59 \ldots 0.75$ & - & $0.51 \ldots 0.59 \ldots 0.64$ & $0.60 \ldots 0.71 \ldots 0.84$ & $0.57 \ldots 0.63 \ldots 0.77$ \\
\hline Density at $12 \% \mathrm{MC}\left(\rho_{12 \%}\right), \mathrm{g} / \mathrm{cm}^{3}$ & $0.53 \ldots 0.63 \ldots 0.79$ & $0.53 \ldots 0.63 \ldots 0.79$ & $0.52 \ldots 0.63 \ldots 0.73$ & $0.63 \ldots 0.74 \ldots 0.87$ & $0.60 \ldots 0.66 \ldots 0.80$ \\
\hline Green wood density $\left(\rho_{\max }\right), \mathrm{g} / \mathrm{cm}^{3}$ & $0.83 \ldots 0.97 \ldots 1.04$ & - & $1.00 \ldots 1.08 \ldots 1.16$ & - & - \\
\hline Basic density $\left(\rho_{y}\right), \mathrm{g} / \mathrm{cm}^{3}$ & 0.547 & - & $0.45 \ldots 0.51 \ldots 0.57$ & - & $0.48 \ldots 0.53 \ldots 0.61$ \\
\hline Maximum MC $\left(W_{\max }\right), \%$ & - & - & $100 \ldots 112 \ldots 133$ & - & - \\
\hline Longitudinal shrinkage $\left(\beta_{1}\right), \%$ & 0.5 & $0.4 \ldots 0.5$ & $0.04 \ldots 0.13 \ldots 0.28$ & - & $0.2 \ldots 0.34^{*}$ \\
\hline Radial shrinkage $\left(\beta_{\mathrm{r}}\right), \%$ & 3.0 & $3.0 \ldots .4 .4$ & $3.5 \ldots .4 .3 \ldots 5.2$ & $1.9 \ldots 5.3 . .8 .0$ & $4.1 \ldots 5.9 \ldots 8.6$ \\
\hline Tangential shrinkage $\left(\beta_{\mathrm{t}}\right), \%$ & 8.0 & $8.0 \ldots 8.5$ & $7.2 \ldots 9.3 \ldots 10.9$ & $9.1 \ldots 11.9 \ldots 15.1$ & $9.6 \ldots 11.2 \ldots 12.8$ \\
\hline Volume shrinkage $\left(\beta_{\mathrm{v}}\right), \%$ & 11.2 & $11.5 \ldots 12.8$ & $11.2 \ldots 14.0 \ldots 16.5$ & $12.5 \ldots 17.4 \ldots 24.8$ & $14.6 \ldots 16.6 \ldots 20.4$ \\
\hline Longitudinal compression strength $\left(\sigma_{\mathrm{c} L}\right), \mathrm{MPa}$ & $29.0 \ldots 49.0 \ldots 72.0$ & 50.0 & $37.4 \ldots 45.5 \ldots 52.8$ & 59.9 & $35.2 \ldots 47.3 \ldots 56.0$ \\
\hline Radial compression strength $\left(\sigma_{\mathrm{c} \mathrm{R}}\right), \mathrm{MPa}$ & - & - & $9.4 \ldots 16.0 \ldots 19.8$ & - & - \\
\hline Tangential compression strength $\left(\sigma_{\mathrm{c}}\right), \mathrm{MPa}$ & - & - & $7.4 \ldots 10.7 \ldots 14.4$ & - & - \\
\hline Bending strength $\left(\sigma_{\mathrm{b}}\right), \mathrm{MPa}$ & $50.0 \ldots 95.0 \ldots 140.0$ & 120.0 & $69.0 \ldots 88.5 \ldots 110$ & 120.7 & $64.9 \ldots 91.7 \ldots 109.6$ \\
\hline Modulus of elasticity at bending (MOE), GPa & $6.4 \ldots 9.4 \ldots 15.2$ & 10.5 & $6.1 \ldots 8.6 \ldots 11.3$ & 11.4 & $6.3 \ldots 10.5 \ldots 18.0^{*}$ \\
\hline Brinell hardness - Cross $\left(H B_{p}\right), N / m^{2}$ & $52.0 \ldots 67.0 \ldots 86.0$ & $48.0 \ldots 61.0$ & $41.5 \ldots 51.4 \ldots 61.7$ & - & 54.0...78.0...110* \\
\hline Brinell hardness - Radial $\left(\mathrm{HB}_{\mathrm{R}}\right), \mathrm{N} / \mathrm{mm}^{2}$ & - & $26.0 \ldots 34.0$ & $18.4 \ldots 24.9 \ldots 31.6$ & - & - \\
\hline Brinell hardness - Tangential $\left(\mathrm{HB}_{\mathrm{T}}\right), \mathrm{N} / \mathrm{mm}^{2}$ & - & $26.0 \ldots 34.0$ & $21.8 \ldots 31.5 \ldots 43.4$ & - & - \\
\hline
\end{tabular}

* Wagenführ (2007) 
When taking in consideration all three measurements of sycamore maple wood (Wagenführ 2007, Ehmcke and Grosser 2014, Sedlar et al. 2019) together and comparing them with average values of beech wood (Štajduhar 1973, Govorčin 1996), densities of beech wood were still approximately $10 \%$ greater than those of sycamore maple wood, except for basic density $(4 \%)$. Bending strength, modulus of elasticity at bending and compression strength parallel to the grain of beech wood were only 5,10 and $15 \%$, respectively, greater than those of sycamore maple wood. The hardness of beech wood was about $35 \%$ greater than that of sycamore maple wood. The difference in shrinkages was 35 up to $50 \%$ between these two wood species. Beech wood had $40 \%$ smaller longitudinal shrinkage.

\subsection{Regression}

Regression equations between oven dry density and shrinkages, annual ring width and densities, and density at $12 \% \mathrm{MC}$ and mechanical properties, as well as statistical significance between properties are shown in Table 2, Table 3 and Table 4, respectively.

The relationship between oven dry density and shrinkages was statistically significant for radial, tangential and volumetric shrinkage of sycamore maple. Radial, tangential, and volumetric shrinkage showed a positive correlation with oven dry density. Investigated shrinkages showed satisfying correlation coefficient with oven dry density, except for longitudinal shrinkage. Pliura et al. (2005) reported a negative correlation between wood density and longitudinal shrinkage, and positive correlations between density and both radial and tangential shrinkage. Koubaa and Smith (1959) observed significant positive correlations between basic wood density, and radial, tangential, and volumetric shrinkage in P. euramericana hybrid clones.

The relationship between annual ring width and densities was statistically significant for all three investigated densities. All investigated densities showed a positive correlation with annual ring width, although the correlation coefficient between properties was low, except in green density. According to Mmolotsi and Teklehaimanot (2006), ring width has little influence on wood density, as the sycamore maple wood is diffuse porous. This means that the growth rate will not affect strength properties although this argument can only be conditional, as strength is also affected by other anatomical and chemical changes associated with faster growth. Numerous studies of a wide range of species have proved inconclusive to assume that growth rate has an influence upon wood density
Table 2 The relationship between oven dry density and shrinkages of sycamore maple wood

\begin{tabular}{|l|c|c|c|c|}
\hline & $R$ & Equation & $F$ & $p$ \\
\hline Longitudinal & 0.0502 & $y=-0.0915 x+0.1854$ & $0.422^{\text {NS }}$ & 0.517 \\
\hline Radial & 0.5363 & $y=6.0301 x+0.7564$ & $67.405^{*}$ & 0.000 \\
\hline Tangential & 0.7092 & $y=15.044 x+0.4923$ & $169.03 *$ & 0.000 \\
\hline Volumetric & 0.7181 & $y=21.049 x+1.7263$ & $177.83 *$ & 0.000 \\
\hline
\end{tabular}

Note: * significant at level $<0.05$; NS - not significant

$R$-coefficient of correlation; $F-F$ statistics; $p$ - significance

Table 3 The relationship between annual ring width and densities of sycamore maple wood

\begin{tabular}{|l|c|c|c|c|}
\hline & $R$ & Equation & $F$ & $p$ \\
\hline Oven dry & 0.2785 & $y=0.0066 x+0.5592$ & $14.043 *$ & 0.000 \\
\hline Basic & 0.2930 & $y=0.0055 x+0.4916$ & $15.681 *$ & 0.000 \\
\hline Maximum MC & 0.5117 & $y=0.0103 x+1.0432$ & $59.234 *$ & 0.000 \\
\hline
\end{tabular}

Note: * significant at level $<0.05$; NS - not significant

$R$-coefficient of correlation; $F-F$ statistics; $p$ - significance

Table 4 The relationship between density at 12\% MC and mechanical properties of sycamore maple wood

\begin{tabular}{|l|c|c|c|c|}
\hline & $R$ & \multicolumn{1}{|c|}{ Equation } & $F$ & $p$ \\
\hline $\begin{array}{l}\text { Compression } \\
\text { Strength, L }\end{array}$ & 0.6838 & $y=61.176 x+7.2556$ & $146.64 *$ & 0.000 \\
\hline $\begin{array}{l}\text { Compression } \\
\text { Strength, } \mathrm{R}\end{array}$ & 0.8788 & $y=48.155 x-14.417$ & $264.51 *$ & 0.000 \\
\hline $\begin{array}{l}\text { Compression } \\
\text { Strength, T }\end{array}$ & 0.9259 & $y=36.033 x-11.876$ & $913.37 *$ & 0.000 \\
\hline $\begin{array}{l}\text { Bending } \\
\text { strength }\end{array}$ & 0.7326 & $y=135.13 x-2.0335$ & $179.52 *$ & 0.000 \\
\hline MOE & 0.4222 & $y=8.8907 x+2.6574$ & $33.630 *$ & 0.000 \\
\hline $\begin{array}{l}\text { Brinell } \\
\text { hardness, C }\end{array}$ & 0.8654 & $y=91.153 x-5.8777$ & $325.21 *$ & 0.000 \\
\hline $\begin{array}{l}\text { Brinell } \\
\text { hardness, R }\end{array}$ & 0.9031 & $y=72.906 x-20.921$ & $491.13 *$ & 0.000 \\
\hline $\begin{array}{l}\text { Brinell } \\
\text { hardness, T }\end{array}$ & 0.8364 & $y=80.315 x-18.922$ & $368.69 *$ & 0.000 \\
\hline
\end{tabular}

Note: * significant at level $<0.05$; NS - not significant;

$R$ - coefficient of correlation $F-F$ statistics; $p$ - significance;

Compression strength $(\mathrm{L}$ - longitudinal direction, $\mathrm{R}$ - radial direction,

$\mathrm{T}$ - tangential direction); Brinell hardness $(\mathrm{C}$ - cross section,

$R$ - radial section, $T$ - tangential section) 
(Zobel and van Buijtenen 1989, Zhang and Zhong 1991, de Castro et al. 1993).

The relationship between density at 12\% MC and mechanical properties was statistically significant for all investigated mechanical properties. All investigated mechanical properties showed a positive correlation with density at $12 \% \mathrm{MC}$, with a high correlation coefficient between properties, except for MOE. Several authors reported different effects of wood density on the mechanical properties of wood (Cown et al. 1999, Alteyrac et al. 2006, Mclean et al. 2016). Some researchers have found that the effects of these traits on the mechanical properties vary between juvenile and mature woods (Cown et al. 1999, Ishiguri et al. 2009, Tanabe et al. 2017 and 2018, Sedlar et al. 2019).

\subsection{Radial Variations}

The radial variations of oven dry density, basic density, green density, and annual ring width are summarized in Fig. 5 and Fig. A1. A slight radial decrease in oven dry density, basic density, green density from pith to bark was observed (with differences from inner to outer areas of $-0.006, p=0.093,-0.002$, $p=0.110$ and $-0.013, p<0.001$, respectively), whereas a
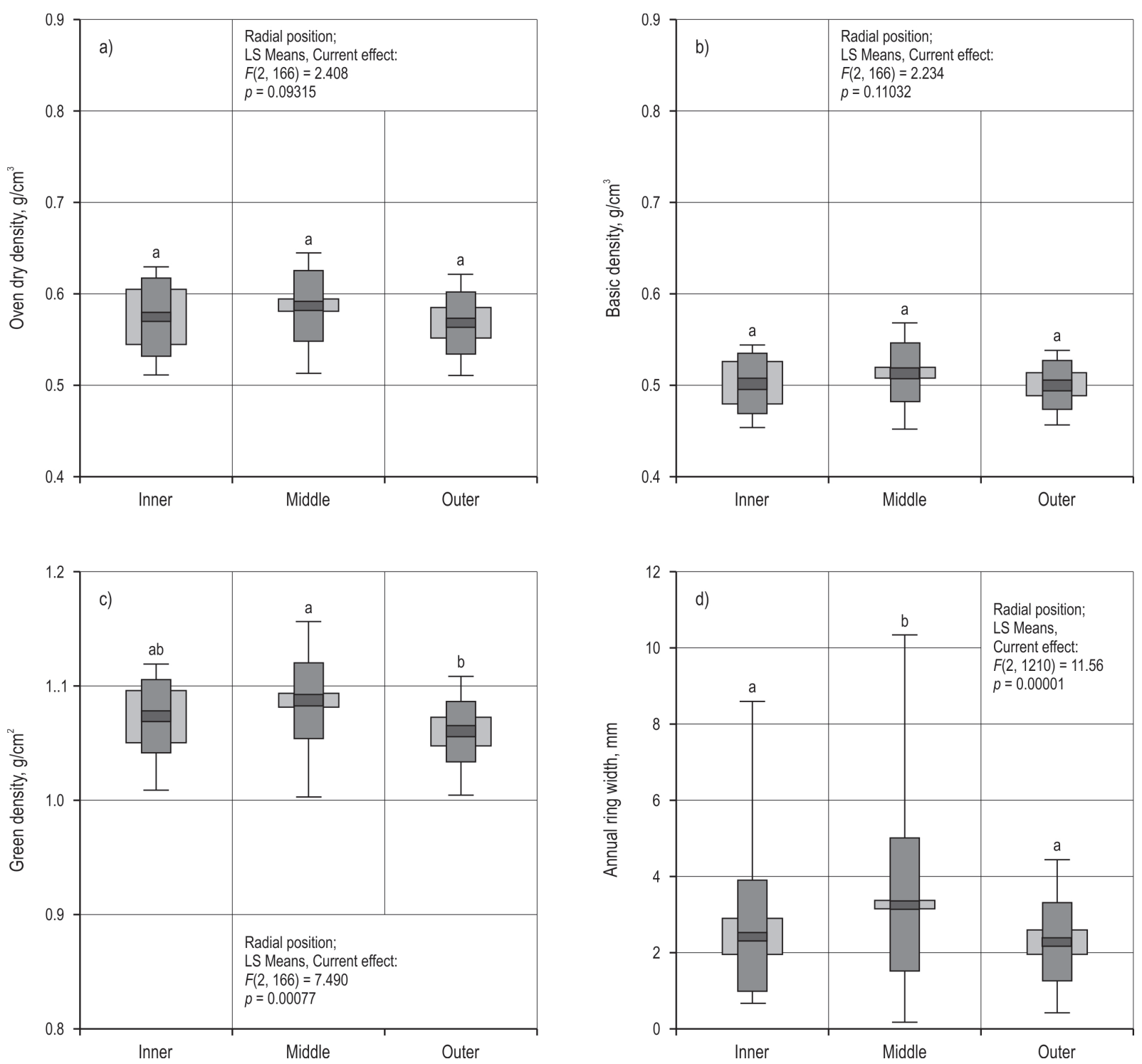

Fig. 5 Radial variations of a) oven dry density, b) basic density, c) green density, and d) annual ring width (The inside area includes the innermost 2-cm-thick samples, the outside area includes the outermost samples, and the middle area includes the remaining samples. The letters above the boxplots identify the statistically significant different groups according to post-hoc Tukey HSD tests. Effective hypothesis decomposition according to One-way ANOVA is given in the graphs.) 

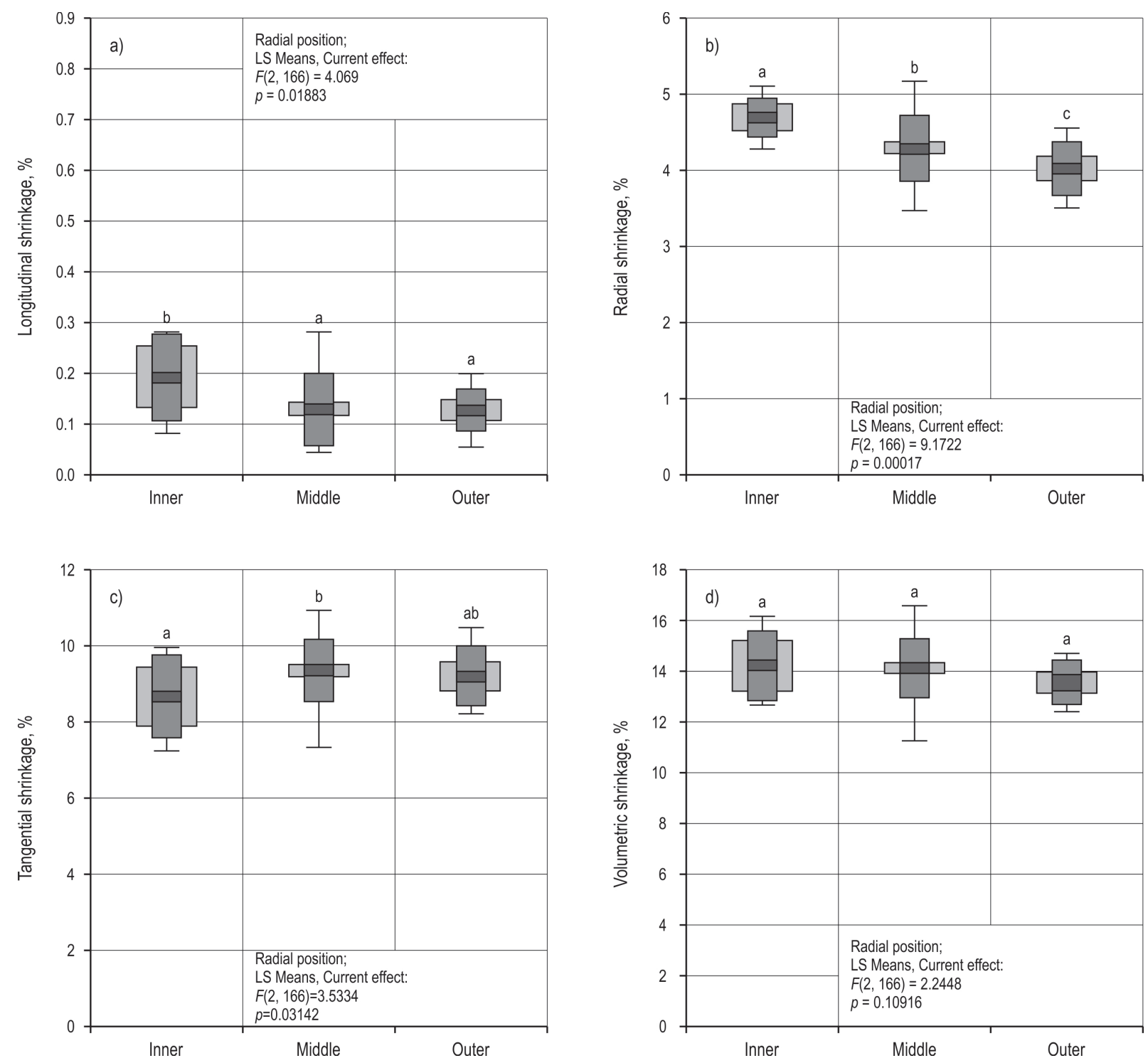

Fig. 6 Radial variations of a) longitudinal, b) radial, c) tangential, and d) volumetric shrinkage (The inside area includes the innermost 2-cmthick samples, the outside area includes the outermost samples, and the middle area includes the remaining samples. The letters above the boxplots identify the statistically significant different groups according to post-hoc Tukey HSD tests. Effective hypothesis decomposition according to One-way ANOVA is given in the graphs.)

radial decrease was observed for annual ring width $(+0.154, p<0.001)$. The radial variation of oven dry density and basic density from pith to bark showed a bell shaped pattern with a slight increase between the inner and middle areas $(+0.012, p=0.330$ and +0.012 , $p=0.246$, respectively) followed by a slight decrease between the middle and outer areas $(-0.019, p=0.042$ and $-0.002, p=0.065$, respectively). The middle area was denser than the inner and outer areas. These could be explained by the annual ring width effect. Densities of wider annual rings were higher than those of thinner annual rings. There was no significant difference between areas in either property. Regarding the green density, the radial increase from pith to bark also showed a bell shaped pattern with a slight increase between the inner and middle area $(+0.015, p=0.159)$ followed by a slight decrease between the middle and outer area $(-0.028, p<0.001)$, only the middle and outer area being statistically different. Radial variations in wood density are often associated with the successional status of species and associated strategies (Woodcock and Shier 2002, Schüller et al. 2013). Woodcock and Shier (2002) proposed a model of radial variations of basic density with a threshold of initial 

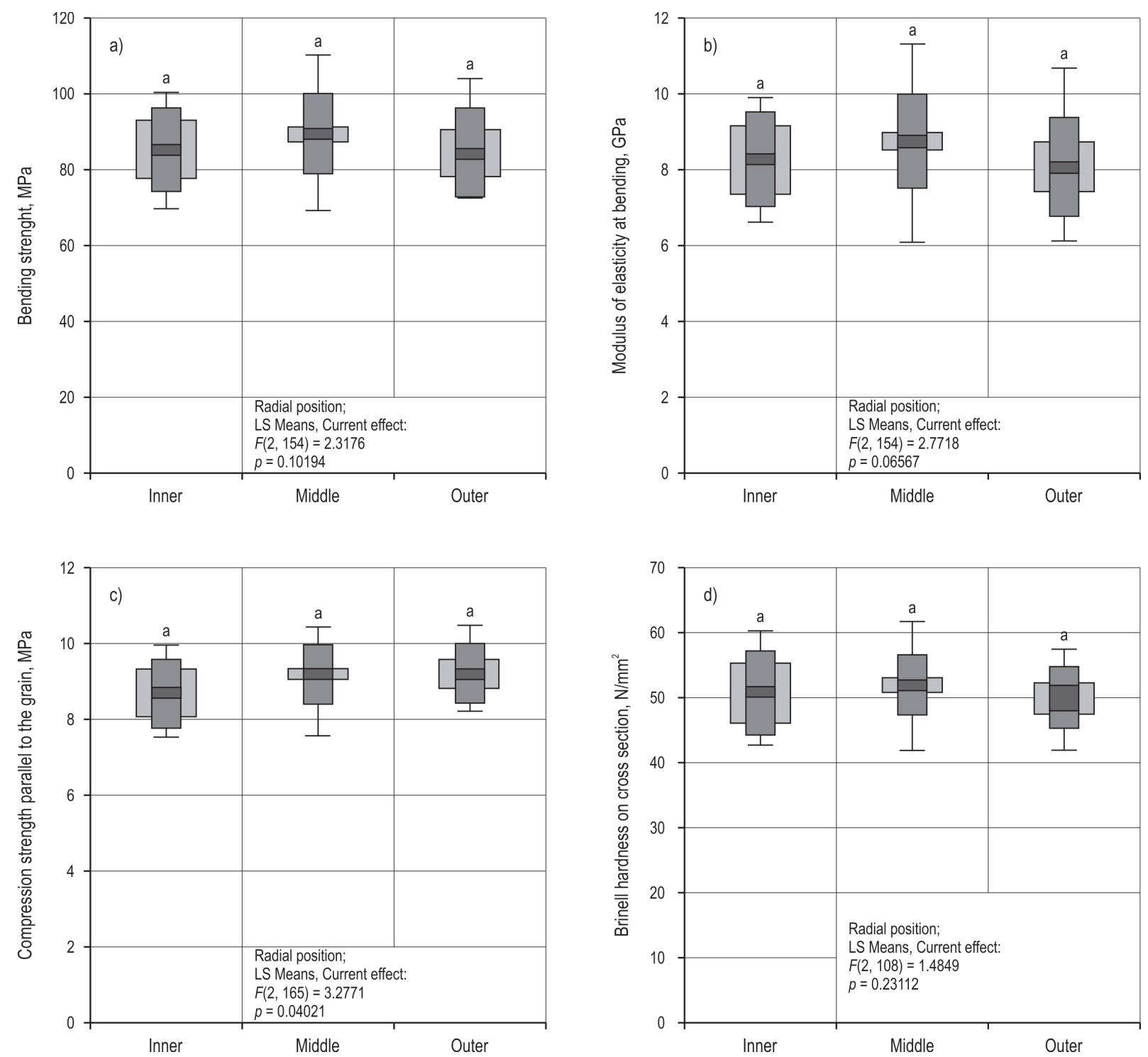

Fig. 7 Radial variations of a) bending strength, b) modulus of elasticity at bending, c) compression strength parallel to the grain, and d) Brinell hardness on cross section (The inside area includes the innermost 2-cm-thick samples, the outside area includes the outermost samples, and the middle area includes the remaining samples. The letters above the boxplots identify the statistically significant different groups according to post-hoc Tukey HSD tests. Effective hypothesis decomposition according to One-way ANOVA is given in the graphs.)

basic density at about $0.55 \mathrm{~g} / \mathrm{cm}^{3}$. This model is valid for hardwood species. Wood species with basic density around $0.55 \mathrm{~g} / \mathrm{cm}^{3}$ have absent or very limited radial variations. Wood species with basic density above $0.55 \mathrm{~g} / \mathrm{cm}^{3}$ show radial decrease in density associated with late-successional characteristics, while wood species below $0.55 \mathrm{~g} / \mathrm{cm}^{3}$ show a radial increase in density associated with early-successional characteristics. According to the definition of inner and outer wood used by Woodcock and Shier (2002) and Plourde et al. (2015), beech and sycamore maple wood was mostly characterized by a radial increase of basic density from inner to outer areas. Longuetaud et al. 2017 measured an overall radial increase in basic densities from pith to bark for beech (Fagus sylvatica) and sycamore maple (Acer pseudoplatanus) with statistical differences from inner to outer areas.

The radial variations of longitudinal, radial, tangential, and volumetric shrinkages are summarized in Fig. 6 and Fig. A2. An overall radial decrease from pith to bark was observed for longitudinal, radial and volumetric shrinkage (with differences in shrinkage from inner to outer areas of $-0.065, p=0.019,-0.672, p<0.001$ and $-0.658, p=0.109$, respectively), whereas the radial 
increase was observed for tangential shrinkage $(+0.536$, $p=0.031$ ). Radial decrease of longitudinal shrinkage was observed with a statistically significant difference between the inner and middle areas $(-0.064, p=0.007)$ followed by a very slight statistically insignificant increase between the middle and outer areas $(+0.001, p=0.940)$. Radial decrease of radial shrinkage was observed with a statistically significant difference between the inner and middle area $(-0.402, p=0.004)$; the decrease was still visible and statistically significant between the middle and outer areas $(-0.270, p=0.007)$. The radial variation of tangential shrinkage from pith to bark showed a bell shaped pattern with a statistically significant increase between the inner and middle area $(+0.688, p=0.010)$ followed by a slight decrease between the middle and outer area $(-0.152, p=0.424)$. Radial decrease of volumetric shrinkage was observed from inner to middle and middle to outer areas with no statistical significance $(-0.111, p=0.765$ and $-0.546, p=0.038$, respectively). The factors that contribute to transverse shrinkage might vary depending on the anatomical structure and its variation within each species (Yamashita et al. 2009). The same authors reported that the radial trends of tangential shrinkage were different among sugi (Cryptomeria japonica) cultivars, while the radial shrinkage increased in all cultivars. Kaburagi (1956) reported that volumetric shrinkage was greater in the outer stem of Larix, Abies, and Pinus, as well as in the inner stem of Fraxinus, Populus, and Picea. In Populus tremula, it was reported that tangential shrinkage was smallest near the pith and rather uniform, whereas radial shrinkage decreased at first and then increased strongly from pith to bark; maximum volume shrinkage was observed in the middle of the cross-section and minimum close to the pith (Kärki 2001).

The radial variations of bending strength, MOE, compression strength parallel to the grain, and Brinell hardness on cross section are summarized in Fig. 7, Fig. A3 and Fig A4. A slight radial decrease in bending strength, $\mathrm{MOE}$, and Brinell hardness on cross section from pith to bark were observed (with differences from inner to outer areas of $-0.937, p=0.101,-0.186$, $p=0.065$, and $-0.781, p=0.231$, respectively). The radial increase was observed for compression strength parallel to grain $(+0.646, p=0.040)$. The radial variation of all mechanical properties above, from pith to bark, showed a bell shaped pattern with a slight increase between the inner and middle areas $(+4.168, p=0.221$, $+0.475, p=0.229,+2.471, p=0.050$ and $+1.194, p=0.455$, respectively) followed by a slight decrease between the middle and outer areas $(-1.975, p=0.092,-1.825$, $p=0.060,-0.661, p=0.035$ and $-5.105, p=0.061$, respectively). There was no significant difference between any areas in all properties. Compression strength in radial and tangential direction, as well as Brinell hardness on radial and tangential section, had the same bell shaped pattern of radial variations, from pith to bark, and insignificant statistical differences of the mechanical properties as shown in Fig. 7. Regarding this investigation, bell shape pattern of radial variation was expected because bending strength, compression strength, and Brinell hardness showed a high positive correlation with wood density.

\section{Conclusions}

The following results were obtained in the present study:

$\Rightarrow$ Wood density of sycamore maple from Medvednica was similar to the findings from known literature, including shrinkages, except for the lower longitudinal shrinkage. Investigated mechanical properties of sycamore maple wood were similar to the findings from known literature, except for the lower bending strength and MOE.

$\Rightarrow$ Investigated sycamore maple indicated better dimensional stability than beech wood from two locations in the region, although it did not match the beech wood regarding mechanical properties, especially wood hardness.

$\Rightarrow$ There was a general bell shaped trend, in the radial direction, in wood density, and mechanical properties of sycamore maple wood. Shrinkages decreased from pith to bark, except for tangential shrinkage with bell shaped increasing pattern.

$\Rightarrow$ There was a positive correlation between wood density, and radial, tangential and volumetric shrinkage, although longitudinal shrinkage was weakly negatively correlated with wood density. All investigated mechanical properties positively correlated with wood density, with a high correlation coefficient between properties, except for MOE. Annual ring width and densities correlated weekly.

$\Rightarrow$ ANOVA indicates that there were no significant differences in wood density and mechanical properties, between inner, middle and outer areas of investigated sycamore maple wood, except for the difference between the middle and outer areas in green density. Shrinkages showed different trends and various significant differences between radial areas. 
$\Rightarrow$ This research enables the assessment of the wood quality for further processing of sycamore maple wood, especially for special wood products (musical instruments, marquetry, souvenirs, veneers, etc.) and better evaluation of sycamore maple as a wood species.

\section{Acknowledgments}

This article is a part of the doctoral thesis of the main author.

\section{References}

Aitken, S.N., Yeaman, S., Holliday, J.A., Wang, T., CurtisMcLane, S., 2008: Adaptation, migration or extirpation: climate change outcomes for tree populations. Evolutionary Applications 1(1): 95-111.https://doi.org/10.1111/j.1752-4571. 2007.00013.x

Alteyrac, J., Cloutier, A., Ung, C.H., Zhang, S.Y., 2006: Mechanical properties in relation to selected wood characteristics of black spruce. Wood and Fiber Science 38(2): 229-237.

Aranda, I., Cano, F.J., Gascó, A., Cochard, H., Nardini, A., Mancha, J.A., López, R., Sánchez-Gómez, D., 2014: Variation in photosynthetic performance and hydraulic architecture across European beech (Fagus sylvatica L.) populations supports the case for local adaptation to water stress. Tree Physiology 35(1): 34-46. https://doi.org/10.1093/treephys/ tpu101

Bell, S., 2009: Valuable broadleaved trees in the landscape: Valuable broadleaved forests in Europe. In: Spiecker, H., Hein, S., Makkonen-Spiecker, K., Thies, M. (eds.) EFI Research-Report, European Forest Institute, Brill: Leiden, Boston, Köln, 171-200 p.

Binggeli, P., 1993: The conservation value of sycamore. The Quarterly Journal of Economcs 87: 143-146.

Brändli U.-B. (ed.) 2010: Schweizerisches Landesforstinventar. Ergebnisse der dritten Erhebung 2004-2006, Eidgenössische Forschungsanstalt für Wald, Schnee und Landschaft WSL, Birmensdorf und Bundesamt für Umwelt (BAFU), Bern.

Cown, D.J., Hebert, J., Ball, R., 1999: Modelling Pinus radiata lumber characteristics. Part 1: mechanical properties of small clears. New Zealand Journal of Forestry Science 29(2): 203-213.

de Castro, F., Williamson, G.B., Moraes de Jesus, R., 1993: Radial variation in the wood specific gravity of Joannesia princeps: the roles of age and diameter. Biotropica 25(2): 176-182.

Ehmcke, G., Grosser, D., 2014: Das Holz der Eiche - Eigenschaften und Verwendung. LWF Wissen 75: 53-64.

Florineth, F., Rauch, H.P., Staffler, H., 2002: Stabilization of landslides with bio-engineering in South Tyrol / Italy and
Thankot / Nepal. Proceedings of the International Congress INTERPRAEVENT 2002 in the Pacific Rim, vol. 2, 827-837 p.

Geßler, A., Keitel, C., Kreuzwieser, J., Matyssek, R., Seiler, W., Rennenberg, H., 2007: Potential risks for European beech (Fagus sylvatica L.) in a changing climate. Trees 21: 1-11. https://doi.org/10.1007/s00468-006-0107-x

Govorčin, S., 1996: Svojstva juvenilnog i adultnog drva bukovine iz područja Bjelolasice. Doctoral thesis, Faculty of Forestry, University of Zagreb, Croatia.

Govorčin, S., Sinković, T., Trajković, J., 2003: Some physical and mechanical properties of beech wood grown in Croatia. Wood Research 48(3): 39-52.

Gustavson, S-I., 2010: The strength properties of Swedish oak and beech. Drewno 53(183): 67-83.

Hein, S., Collet, C., Ammer, C., Le Goff, N., Skovsgaard, J.P., Savill, P., 2009: A review of growth and stand dynamics of Acer pseudoplatanus L. in Europe: implications for silviculture. Forestry 82(4): 361-386. https://doi.org/10.1093/forestry/cpn043

Heitz R., Rehfuess K.E., 1999: Reconversion of Norway spruce (Picea abies /L./ Karst.) stands into mixed forests: effects on soil properties and nutrient fluxes. Management of mixed-species forest: silviculture and economics (ed. by Olsthoorn, A.F.M., Bartelink, H.H., Gardiner, J.J., Pretzsch, H., Hekhuis, H.J., Franc, A.) IBN Scientific Contributions, 46-57 p.

Ishiguri, F., Terazawa, E., Sanpe, H., Matsumoto, K., Ishido, M., Ohno, H., Iizuka, K., Yokota, S., Yoshizawa, N., 2009: Radial variation and difference between juvenile wood and mature wood in bending property of sugi (Cryptomeria japonica D. Don) originated from seedlings. Wood Industry 64(1): 20-25.

Kaburagi, Z., 1956: Forest-biological studies on wood quality. (Report 13) On the volumetric shrinkage of wood of the planted trees grown at Nopporo district in Hokkaido. Bull Gov Forest Exp Stat 90: 109-144.

Kärki, T., 2001: Variation of wood density and shrinkage in European aspen (Populus tremula). Holz Roh Werkst 59(1-2): 79-84.

Koubaa, R.W., Smith, J.H.G., 1959: The effect of some genetic and environmental factors on wood quality in poplar. Pulp \& Paper J 59: 37-38.

Kölling, C., 2007: Klimahüllen für 27 Waldbaumarten. Allgemeine Forstzeitschrift/Der Wald. 23: 1242-1245.

Kölling, C., Zimmermann, L., 2007: Die Anfälligkeit der Wälder Deutschlands gegenüber dem Klimawandel. Gefahrstoffe 67(6): 259-268.

Krabel, D., Wolf, H., 2013: Sycamore maple (Acer pseudoplatanus L.). In: Pâques L.E. (ed) Forest tree breeding in Europe. Springer, Netherlands, 373-402 p. 
Leslie, A.D., 2005: The ecology and biodiversity value of sycamore (Acer pseudoplatanus L.) with particular reference to Great Britain. Scottish Forestry 59(3): 19-26.

Lo Monaco, A., Calienno, L., Pelosi, C., Balletti, F., Agresti, G., Picchio, R., 2015: Technical properties of beech wood from aged coppices in Italy. iForest 8(1): 82-88. https://doi. org/10.3832/ifor1136-007

Mariotti, B., Alberti, G., Maltoni, A., Andrea Tani, A., Piussi, P., 2017: Beech coppice conversion to high forest: results from a 31-year experiment in Eastern Pre-Alps. Annals of Forest Science 74: 44. https://doi.org/10.1007/s13595-0170642-1

Matović, B., 2019: Starosna struktura visokih monodominantnih bukovih šuma u Srbiji. Šumarstvo 3-4: 105-116.

McLean, J.P., Moore, J.R., Gardiner, B.A., Lee, S.J., Mochan, S.J., Jarvis, M.C., 2016: Variation of radial wood properties from genetically improved Sitka spruce growing in the UK. Forestry 89(2): 109-116. https://doi.org/10.1093/forestry/ cpv035

Mmolotsi, R.M., Teklehaimanot, Z., 2006: The effect of initial tree-planting density on timber and wood-fuel properties of red alder and sycamore. Canadian Journal of Forest Research 36(6): 1475-1483. https://doi.org/10.1139/x06-029

Müller-Haubold, H., Hertel, D., Leuschner, C., 2015: Climatic drivers of mast fruiting in European beech and resulting $\mathrm{C}$ and $\mathrm{N}$ allocation shifts. Ecosystems 18: 1083-1100. https://doi.org/10.1007/s10021-015-9885-6

Pasta, S., de Rigo, D., Caudullo, G., 2016: Acer pseudoplatanus in Europe: distribution, habitat, usage and threats. In: SanMiguel- Ayanz, J., de Rigo, D., Caudullo, G., Houston Durrant, T., Mauri, A. (Eds.), European Atlas of Forest Tree Species. Publ. Off. EU, Luxembourg, 56-57 p. https://doi. org/10.2788/4251

Petrić, B., Šćukanec, V., 1986: Struktura drva domaće bukve (Fagus silvatica L.), Referat na kolokviju o bukvi, Velika, 22-24. 11. 1984., Kolokvij o bukvi, Šumarski fakultet Zagreb.

Pliura, A., Yu, Q., Zhang, S.Y., Mackay, J., Pierre, P., Bousquet, J., 2005: Variation in wood density and shrinkage and their relationship to growth young poplar hybrids crosses. Forest Science Journal 51(5): 472-482. https://doi.org/10.1093/ forestscience/51.5.472

Rusanen, M., Myking, T., 2003: EUFORGEN Technical Guidelines for genetic conservation and use for sycamore (Acer pseudoplatanus). International Plant Genetic Resources Institute, Rome, Italy.

Sagnard, F., Pichot, C., Dreyfus, P., Jordano, P., Fady, B., 2007: Modelling seed dispersal to predict seedling recruitment: Recolonization dynamics in a plantation forest. Ecological modelling 203(3-4): 464-474. https://doi.org/10.1016/j. ecolmodel.2006.12.008

Samonil, P., Antolik, L., Svoboda, M., Adam, D., 2009: Dynamics of windthrow events in a natural fir-beech forest in the Carpathian Mountains. Forest Ecology and Manage- ment 257(3): 1148-1156. https://doi.org/10.1016/j.foreco.2008.11.024

Saranpää, P., 2003: Wood density and growth. In: Wood quality and its biological basis, 1st ed.; Barnett, J.R., Jeronimidis, G.; Blackwell Publishing Ltd, 9600 Garsington Road, Oxford, UK, Chapter 4: 87-117.

Savidge, R.A., 2003: Tree growth and wood quality. In: Wood quality and its biological basis, 1st ed.; Barnett, J.R., Jeronimidis, G.; Blackwell Publishing Ltd, 9600 Garsington Road, Oxford, UK, Chapter 1: 1-29.

Scarvelis, M., Matanis, G.I., 2013: Physical and mechanical properties of beech wood harvested in Greek public forests. Wood Research 58(1): 123-130.

Sedlar, T., Sinković, T., Perić, I., Jarc, A., Stojnic, S., Šefc, B., 2019: Hardness of thermally modified beech wood and hornbeam wood. Šumarski list 143(9-10): 433-433. https:// doi.org/10.31298/sl.143.9-10.4

Sedlar, T., Sinković, T., Trajković, J., Hasan, M., Ištok, I., Šefc, B., 2019: Physical Properties of Juvenile and Mature Sycamore Maple (Acer pseudoplatanus L.) Wood from Medvednica Region. Drvna industrija 70(1): 19-26. https://doi. org/10.5552/drvind.2019.1762

Simon, J., Waldhecker, P., Brüggemann, N., Rennenberg, H., 2010: Competition for nitrogen sources between European beech (Fagus sylvatica) and sycamore maple (Acer pseudoplatanus) seedlings. Plant Biology 12(3): 453-458. https://doi. org/10.1111/j.1438-8677.2009.00225.x

Sinković, T., Govorčin, S., Sedlar, T., 2011: Comparison of physical properties of untreated and heat treated beech and hornbeam wood. Drvna Industrija 62(4): 283-290. https:// doi.org/10.5552/drind.2011.1118

Sonderegger, W., Martienssen, A., Nitsche, C., Ozyhar, T., Kaliske, M., Niemz, P., 2013: Investigations on the physical and mechanical behavior of sycamore maple (Acer pseudoplatanus L.). European Journal of Wood and Wood Products 71: 91-99. https://doi.org/10.1007/s00107-012-0641-8

Spiecker, H., Hein, S., Makonnen-Spiecker, K., Thies, M., 2009: Distribution of valuable broadleaved forests in Europe, Appendix B. In Valuable Broadleaved Forests in Europe. EFI Research-Report 22. European Forest Institute, Joensuu, Finland, 256 p.

Stamm, A.J., Sanders, H.T., 1966: Specific gravity of the wood substance of loblolly pine as affected by chemical composition. TAPPI 49(9): 397-400.

Stojnić, S., Suchocka, M., Benito-Garzón, M., Torres-Ruiz, J.M., Cochard, H., Bolte, A., Cocozza, C., Cvjetković, B., de Luis, M., Martinez-Vilalta, J., Ræbild, A., Tognetti, R., Delzon, S., 2018: Variation in xylem vulnerability to embolism in European beech from geographically marginal populations. Tree Physiology 38(2): 173-185. https://doi.org/10.1093/ treephys/tpx128

Straigyte, L., Baliuckas, V., 2015: Spread intensity and invasiveness of sycamore maple (Acer pseudoplatanus L.) in Lith- 
uanian forests. iForest 8(5): 693-699. https://doi.org/10.3832/ ifor0763-007

Štajduhar, F., 1973: Prilog istraživanja fizičko-mehaničkih svojstava bukovine u Hrvatskoj. Drvna industrija 24 (3-4): 43-59.

Tanabe, J., Ishiguri, F., Tamura, A., Ohshima, J., Iizuka, K., Yokota, S., 2017: Radial and between family variations of the microfibril angle and the relationships with bending properties in Picea jezoensis families. Scandinavian Journal of Forest Research 32(1): 39-44. https://doi.org/10.1080/02827581.201 6.1186217

Tanabe, J., Ishiguri, F., Tamura, A., Takashima, Y., Ohshima, J., lizuka, K., Yokota, S., 2018: Within-tree radial and amongfamily variations in wood density, microfibril angle, and mechanical properties in Picea glehnii. Silva Fennica 52(2): article id 9914. https://doi.org/10.14214/sf.9914

Thies, M., Hein, S., Spiecker, H., 2009: Results of a questionnaire on management of valuable broadleaved forests in Europe. In: Spiecker, H., Hein, S., Makkonen-Spiecker, K., Thies, M. (eds.). Valuable broadleaved forests in Europe. Boston: European Forest Institute: Research Report 22, 27-42 p.

Trotsiuk, V., Hobi, L.M., Commarmot, B., 2012: Age structure and disturbance dynamics of the relic virgin beech forest Uholka (Ukrainian Carpathians). Forest Ecology and Management 265: 181-190. https://doi.org/10.1016/j.foreco.2011.10.042

Wagenführ, R.S., 2007: Holzatlas, $6^{\text {th }}$ edn. Fachbuchverlag, Lepzig.

Woodcock, D., Shier, A., 2002: Wood specific gravity and its radial variations: the many ways to make a tree. Trees 16 : 437-443. https://doi.org/10.1007/s00468-002-0173-7

Vacek, S., Vacek, Z., Kalousková, I., Cukor, J., Bílek, L., Moser, K.W., Bulušek, D., Podrázský, V., Řeháček, D., 2018: Sycamore maple (Acer pseudoplatanus L.) stands on former agricultural land in the Sudetes - evaluation of ecological value and production potential. Dendrobiology 79: 61-76. http://dx.doi.org/10.12657/denbio.079.006

Yamashita, K., Hirakawa, Y., Nakatani, H., Ikeda, M., 2009: Tangential and radial shrinkage variation within trees in sugi (Cryptomeria japonica) cultivars. Jorunal of Wood Science 55: 161-168. https://doi.org/10.1007/s10086-008-1012-2

Zink-Sharp, A., 2003: The mechanical properties of wood. In: Wood quality and its biological basis, 1st ed.; Barnett, J.R., Jeronimidis, G.; Blackwell Publishing Ltd, 9600 Garsington Road, Oxford, UK, Chapter 8: 187-210.

Zhang, S.Y., Zhong, Y., 1991: Effect of growth rate on specific gravity of East-Liaoning oak (Quercus liatungensis) wood. Canadian Journal of Forest Research 21(2): 255-260. https://doi.org/10.1139/x91-031

Zhang, S.Y., 2003: Wood quality attributes and their impacts on wood utilization. Proceedings from the XII World Forestry Congress, Quebec City, Canada.
Zobel, B., 1984: The changing quality of the world wood supply. Wood Science and Technology 18: 1-17. https://doi. org/10.1007/BF00632127

Zobel, B.J., van Buijtenen, J.P., 1989: Wood Variation and Wood Properties. In: Wood Variation. Springer Series in Wood Science. Springer, Berlin, Heidelberg. https://doi. org/10.1007/978-3-642-74069-5_1

Distribution map of Sycamore (Acer pseudoplatanus) EUFORGEN 2009, www.euforgen.org.

Hrvatske šume, 2019: Cjenik glavnih šumskih proizvoda, svibanj 2019.

EN 1309-3:2018: Round and sawn timber - methods of measurements - part 3: features and biological degradations.

ISO 3129:2012 Wood - Sampling methods and general requirements for physical and mechanical testing of small clear wood specimens.

ISO 13061-1:2014 Physical and mechanical properties of wood - Test methods for small clear wood specimens Part 1: Determination of moisture content for physical and mechanical tests.

ISO 13061-2:2014 Physical and mechanical properties of wood - Test methods for small clear wood specimens Part 2: Determination of density for physical and mechanical tests.

ISO 13061-3:2014 Physical and mechanical properties of wood - Test methods for small clear wood specimens Part 3: Determination of ultimate strength in static bending.

ISO 13061-4:2014 Physical and mechanical properties of wood - Test methods for small clear wood specimens Part 4: Determination of modulus of elasticity in static bending.

ISO 13061-5:2020 Physical and mechanical properties of wood - Test methods for small clear wood specimens Part 5: Determination of strength in compression perpendicular to grain.

ISO 13061-12:2017 Physical and mechanical properties of wood - Test methods for small clear wood specimens Part 12: Determination of static hardness.

ISO 13061-13:2016 Physical and mechanical properties of wood - Test methods for small clear wood specimens Part 13: Determination of radial and tangential shrinkage.

ISO 13061-14:2016 Physical and mechanical properties of wood - Test methods for small clear wood specimens Part 14: Determination of volumetric shrinkage.

ISO 13061-17:2017 Physical and mechanical properties of wood - Test methods for small clear wood specimens Part 17: Determination of ultimate stress in compression parallel to grain. 
T. Sedlar et al. Wood Quality Characterization of Sycamore Maple (Acer pseudoplatanus L.) and its Utilization ... (543-560)

\section{Appendix}

\section{Radial variations from pith to bark}

Variations of investigated properties with radius (distance from the pith in the annual ring).
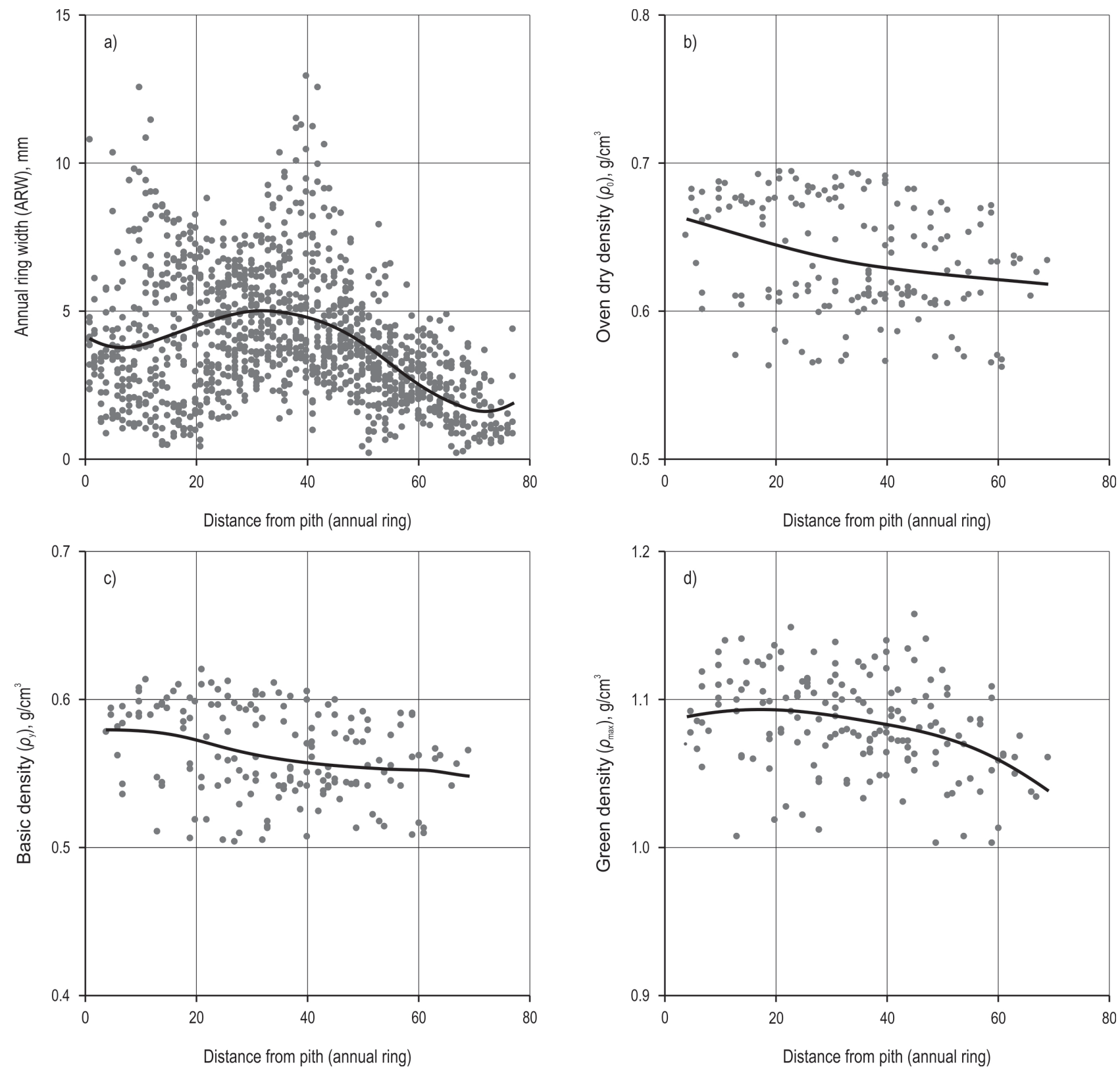

Fig. A1 Variations of a) annual ring width (ARW), b) oven dry density $\left(\rho_{0}\right)$, c) basic density $\left(\rho_{\mathrm{y}}\right)$, and d) green density $\left(\rho_{\text {max }}\right)$ from pith to bark (Each point represents the average of one $2 \mathrm{~cm}$-thick samples except at annual ring width where it represents one annual ring; the solid lines show the LOESS smoothing for each property (Sedlar et al. 2019).) 

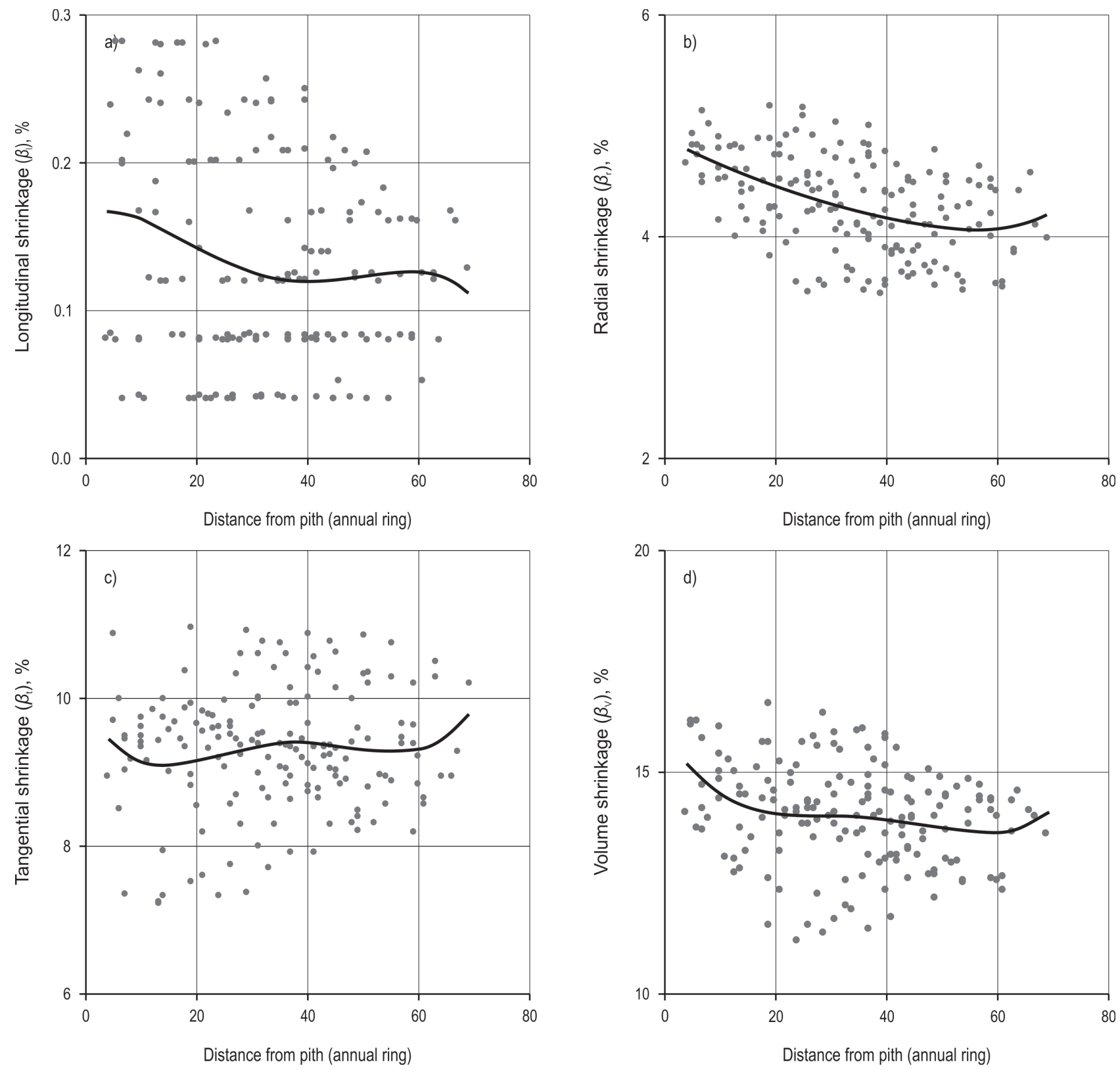

Fig. A2 Variations of a) longitudinal $\left(\beta_{\mathrm{l}}\right)$, b) radial $\left.\left(\beta_{\mathrm{r}}\right), \mathrm{c}\right)$ tangential $\left(\beta_{\mathrm{t}}\right)$, and d) volume $\left(\beta_{\mathrm{v}}\right)$ shrinkage from pith to bark (Each point represents the average of one $2 \mathrm{~cm}$-thick samples; the solid lines show the LOESS smoothing for each property (Sedlar et al. 2019).) 
T. Sedlar et al. Wood Quality Characterization of Sycamore Maple (Acer pseudoplatanus L.) and its Utilization ... (543-560)
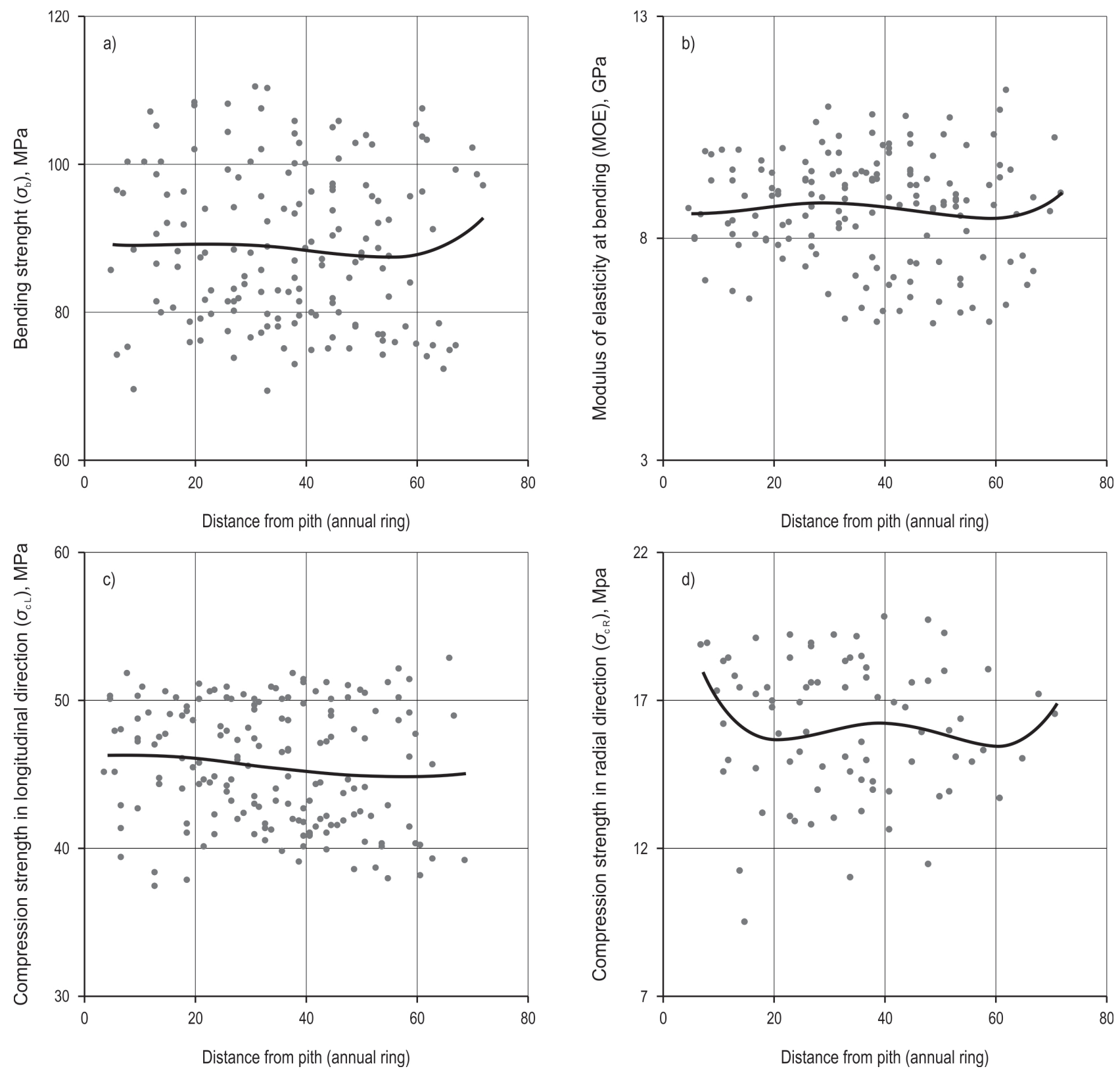

Fig. A3 Variations of a) bending strength $\left(\sigma_{b}\right)$, b) modulus of elasticity at bending (MOE), compression strength in c) longitudinal $\left(\sigma_{\mathrm{c} L}\right)$ and d) radial $\left(\sigma_{\mathrm{c}}\right)$ direction; from pith to bark (Each point represents the average of one $2 \mathrm{~cm}$-thick samples; the solid lines show the LOESS smoothing for each property.) 

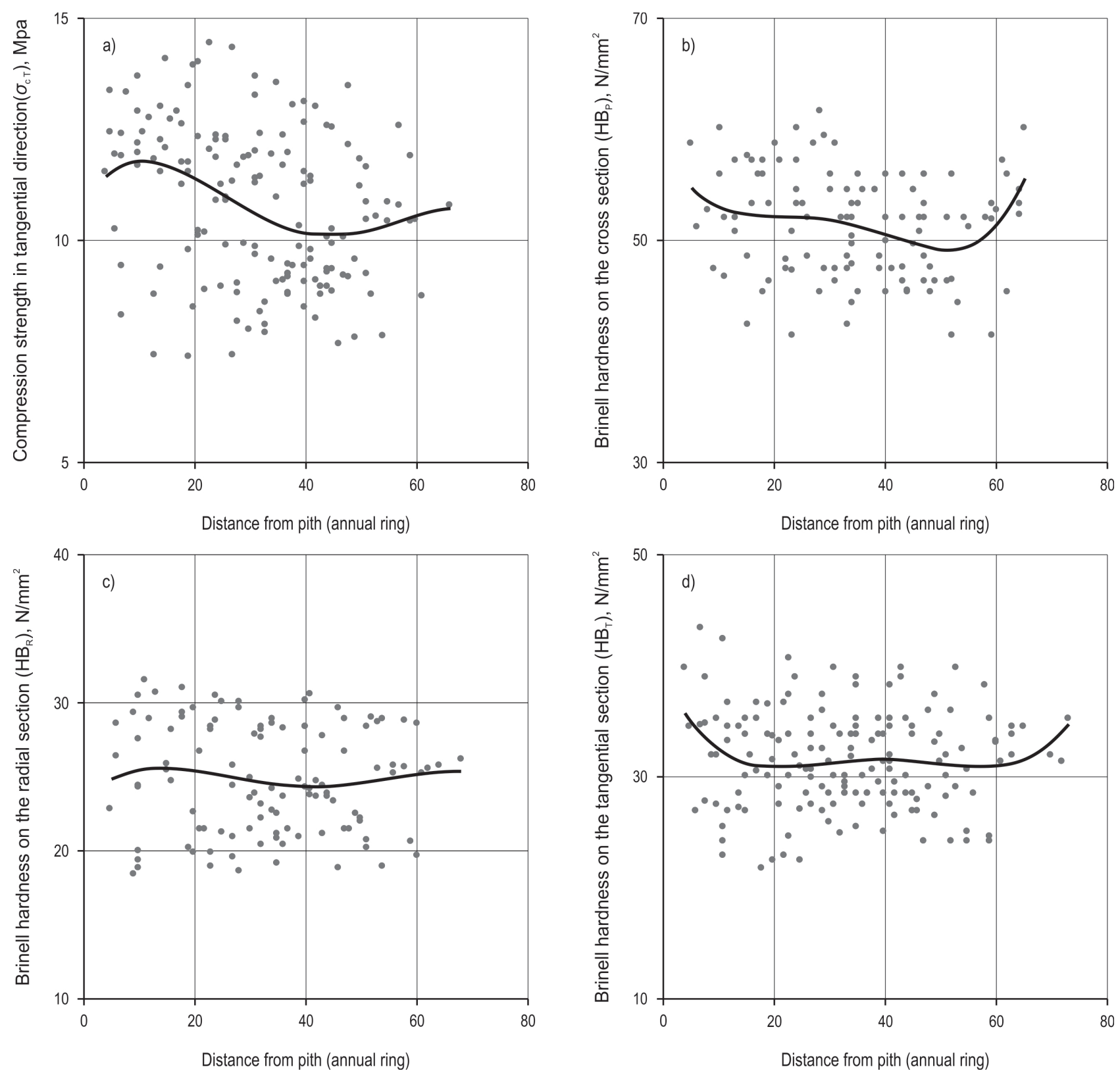

Fig. A4 Variations of a) compression strength in tangential $\left(\sigma_{\mathrm{c} T}\right)$ direction, Brinell hardness on the b) cross $\left.\left(H \mathrm{~B}_{\mathrm{p}}\right), \mathrm{c}\right)$ radial $\left(\mathrm{HB}_{\mathrm{R}}\right)$ and $\left.\mathrm{d}\right)$ tangential $\left(\mathrm{HB}_{\mathrm{T}}\right)$ section; from pith to bark (Each point represents the average of one $2 \mathrm{~cm}$-thick samples; the solid lines show the LOESS smoothing for each property.) 
T. Sedlar et al. Wood Quality Characterization of Sycamore Maple (Acer pseudoplatanus L.) and its Utilization ... (543-560)

(C) 2021 by the authors. Submitted for possible open access publication under the terms and conditions of the Creative Commons Attribution (CC BY) license (http://creativecommons.org/licenses/by/4.0/).

Authors' addresses:

Assist. prof. Tomislav Sedlar, $\mathrm{PhD}$

e-mail: tsedlar@sumfak.unizg.hr

Assoc. prof. Bogoslav Šefc, PhD *

e-mail: bsefc@sumfak.unizg.hr

Prof. Tomislav Sinković, PhD

e-mail: tsinkovic@sumfak.unizg.hr

University of Zagreb

Faculty of Forestry and Wood Technology

Svetošimunska cesta 23

10002 Zagreb

CROATIA

Srđan Stojnić, $\mathrm{PhD}$

e-mail: srdjan.stojnic@uns.ac.rs

University of Novi Sad

Institute of Lowland Forestry and Environment

Antona Čehova $13 \mathrm{~d}$

21000 Novi Sad

Received: 1 July 2020

SERBIA

Accepted: 19 January 2021

* Corresponding author 